\title{
Leader Effects and Voting for the Populist Radical Right in Western Europe
}

\author{
Elie Michel $^{1}$ (D), Diego Garzia ${ }^{2}$ (D), \\ Frederico Ferreira da Silva ${ }^{2}$ (iD and Andrea De Angelis ${ }^{1}$ (iD \\ ${ }^{1}$ University of Lucerne \\ ${ }^{2}$ University of Lausanne
}

\begin{abstract}
Charismatic leaders are often assumed to drive the electoral success of populist radical right parties. Yet, little attention is given to how voter evaluations of leaders influence individual voting behavior. To our knowledge, no systematic and comparative tests of this empirical question exist. In this paper, we test to what extent voters' support for populist radical right parties is fueled by leaders' appreciation. In order to examine leader effects on the populist radical right vote, we rely on an original dataset pooling 29 National Election Studies from ten established West European parliamentary democracies (1985-2018). Our analysis finds that: (1) voters' evaluation of party leaders is significantly associated with voting for populist radical right parties; (2) leader evaluations are more important than left-right self-placement when it comes to voting for the populist radical right, and (3) leader effects are more important for populist radical right voters than for other voters.
\end{abstract}

Keywords: Leader effect, Populist radical right, Charismatic leaders, Personalization of politics

\section{Introduction}

Over the last decades, Western democracies have undergone a decline in the significance of social identities, such as class or religion, for political attitudes and behavior (Evans 1999, Dalton 2013). The loyalty ties linking voters and parties have weakened, and voters became more permeable to the influence of short-term factors associated with the electoral context and to election campaigns (Dalton et al. 2002). As a result, recent research shows that feelings towards party leaders have come to influence voters' attitudes and behavior more over time (Garzia 2014; Rahat and Kenig 2018). The personalization of politics has affected both the demand- and supply-side of electoral politics, and parties themselves have undergone major transformations (McAllister 2007). Notably, their organization has evolved: while party membership and activism have declined, the party leaders' role has become increasingly determinant (Diamond and Gunther 2001; Poguntke and Webb 2005). Political leaders are also increasingly important figures in public opinion and the media, particularly during election campaigns (van Aelst et al. 2012, Boumans et al. 2013; Takens et al. 2015; Garzia et al. 2020). The growing importance of political leaders thus has significant consequences in terms of voting behavior. The primary theoretical expectation deriving from the personalization of politics' framework, therefore, conceives individuals as "increasingly voting for a person, and no longer only for a party or a platform" (Manin 1995, p.279). The evaluation of political leaders and candidates is increasingly relevant to 
voters' choice, and extensive research studies the "leader effect" on voting behavior (for overviews see Aarts et al. 2011; Lobo and Curtice, 2014; Garzia 2017).

Parallel to this trend of personalization, populist radical right parties have surged across Europe since the 1980s (Kriesi 2014). Although the populist radical right label includes heterogeneous parties in terms of policy positions, constituencies, political relevance, and government participation, the parties still constitute a coherent party family. The populist radical right is defined by two ideological features: nativism (which is specific to the radical right) and populism (not specific to this party family) (Mudde 2010). The radical right's nativism is an "ideology which holds that states should be inhabited exclusively by members of the native group ("the nation") and that non-native elements (persons and ideas) are fundamentally threatening to the nation-state's homogeneity" (Mudde 2007: 19). On the other hand, populism is a claim to represent the "true people" against a "corrupt elite". Still, the claim deserves the qualification that "populism advocates the power of the people, yet it relies on the seduction by a charismatic leader" (Mény and Surel 2002: 17). ${ }^{1}$ Indeed, the populist radical right is widely associated with charismatic leaderships. Particularly, the most typical and successful cases of West European populist radical right parties have emerged under the aura of a charismatic leader: Jean-Marie Le Pen's Front National, Jörg Haider's Freiheitliche Partei Österreichs, Umberto Bossi's Lega Nord, Pia Kjaersgaard's Dansk Folkeparti, or Geert Wilders' Partij voor de Vrijheid (Kefford and McDonnell 2018). Exceptions exist and some populist radical right parties indeed lack a charismatic leader (e.g. the Swedish Sverigedemokraterna of Jimmie Akesson or the Norwegian Fremskrittpartiet of Siv Jensen). Notwithstanding, voters' appeal for the party leader is assumed to be a determining factor in explaining the electoral success of modern radical right parties (Ignazi 2003, van Kessel 2015). As of today, however, very little attention has been devoted to this issue from the perspective of quantitative voting behavior research.

In this paper, we offer the broadest comparative assessment to date of leaders' relevance for the populist radical right's electoral success, in the framework of the personalization of politics. We are not arguing that party leader-centrism is driving the populist radical right's electoral success - which is based on a combination of structural factors and political dynamics (Kriesi and Schulte-Cloos 2020). Rather, we consider a high level of personalization to be one of the conditions for successful party leadership to develop, which, in turn, facilitates the growth of populist movements (Poguntke and Webb 2018). In this paper, we address the question of the (extent of the) influence of leader effects on the populist radical right vote. ${ }^{2}$ Strikingly, the literature on personalization and leader effects on electoral behavior has only scarcely studied populist radical right parties. Building on the pioneering work of van der Brug and Mughan (2007), we test the extent to which positive evaluations of populist radical right leaders are connected to voters' support for these parties. Two specific sub-questions follow from this our research question: How do leader effects compare to other drivers of the populist radical right

\footnotetext{
${ }^{1}$ There is an extensive literature on the theoretical discussion on populism. Some authors do not consider populism to be an ideology, but rather as a political style (Moffit and Tormey, 2014). In all cases, all radical right parties in Western Europe are consensually considered populist - and different conceptualization of populism underlie the "centrality of the leader" (Moffit 2016).

${ }^{2}$ We acknowledge that other parties may be considered populist, however, we do not include them in our analyses. We focus on the Populist Radical Right, as most studies highlight the role of their leaders. Conversely, Populist Radical Left parties are more rarely associated to a given party leader - but more often associated to a collective leadership, and to more strongly identified issues. Consequently, we cannot expect that leader evaluations would matter more than ideological characteristics for Populist Radical Left voters.
} 
vote? How do they compare to leader effects for other party choices? In order to examine these questions, we rely on an original dataset pooling 29 National Election Studies from ten established West European parliamentary democracies (1985-2018). Our analysis finds that (1) voters' evaluation of the party leaders is significantly associated with voting for populist radical rights parties; (2) that leader evaluation is more important than long-term ideological variables when it comes to voting for the populist radical right; and (3) that leader effects are more important for populist radical right voters than for other voters.

\section{Leader Effects and the Populist Radical Right}

The expected importance of party leaders for the populist radical right has been examined through two approaches, which we will label as the "charismatic leadership" and the "leader effect" approaches.

The concept of charismatic leadership originates in the early analyses of Max Weber, defined as a mass affective bond between the charismatic leader and his followers (1978). Yet, in contemporary West European electoral politics, there seems to be no mass affective bond between citizens and political leaders, making the concept ill-fitting. In the age of television, and perhaps even more of social media, the distance between the public and political leaders has been reduced: there is a "lowering effect" of political leaders to the level of their audience (Meyrowitz 1985). Many populist radical right leaders are considered charismatic because they are influential personalities, good speakers, and "media-savvy", i.e., talented at securing media attention and profiting as much as they can from it (Mazzoleni 2008). These characteristics are not specific to populist radical right leaders, however, and some even lack them. Following this agent-based definition of charisma, populist radical right leaders can therefore become charismatic but can also lose their charisma (Wodak 2015).

The success of the populist radical right is also more specifically explained through "coterie charisma", i.e. the capacity of party leaders to attract a core of supporters who praise the leader's unique qualities, are connected through strong emotional ties and an established network, and who vest him or her with a special mission (Eatwell 2002, McDonnell 2016). While this type of charismatic leadership is not specific to the populist radical right, it is decisive for their electoral success (de Lange and Art 2011). On the other hand, "centripetal charisma" is specific to the populist radical right parties: voters come to see parties - particularly of the populist radical right - through the matrix of their leaders, who have a "homogenizing party image" over issues and policies, representing the party in all its dimensions (Eatwell 2018). Yet, while the charismatic leadership approach provides an appealing theory, current research has not been able to empirically assess its validly. So far, this literature tends to resort to an aphorism: charismatic leaders are the most electorally successful ones, and reciprocally. As Mudde (2007: 262) puts it, "the key problem with the variable 'charismatic leader' is the vagueness of the term". Because of conceptual limitations, and lack of adequate data, authors have argued that the concept of charismatic leadership has little empirical relevance to study the success of radical right parties and that "this explanation of support for populist parties is not open to empirical falsification" (van der Brug and Mughan 2007: 44). In this paper, we thus acknowledge these measurement and operationalization limits and resort to a micro-behavioral approach which "leaves the ambivalent notion of charisma aside" (Kestilä-Kekkonen and Söderlund 2014). 
The theoretical coordinates of our inquiry are located within the literature on behavioral personalization. This literature points to the relevance of political leadership for voting behavior as a function of voters' subjective perceptions. This approach fits into the broader personalization of politics thesis (McAllister 2007; Garzia 2014). This describes a process through which individual political actors have gained relevance at the expense of collective political organizations such as political parties (Rahat and Sheafer 2007). The concept of personalization is both longitudinal (it assumes an increase in the importance of political actors across time) and multidimensional (it may be present in multiple political arenas, affecting political institutions, the media and individual voting behavior) (Pedersen and Rahat 2019). Within the latter dimension, the literature distinguishes between centralized personalization (which refers to a process taking place at the party leadership level) and decentralized personalization (which relates to the increased relevance of individual politicians aside from the party leader) (Balmas et al. 2014). On these bases, our analysis of leader effects on radical right party support insists on the centralized subdimension of behavioral personalization.

While initial studies questioned the very existence of leader effects on the vote (King 2002), more recent research has cumulatively demonstrated the importance of voters' evaluations of political leaders for vote choice (Bittner 2011, Garzia 2014). When it comes to the longitudinal dimension of behavioral personalization, however, existing works have yet been unable to consistently demonstrate a growth in leader effects across time. As underlined before, the concept of personalization is intrinsically longitudinal, as it presupposes a change across time to more personalized patterns of voting behavior. However, the results stemming from existing studies remain inconclusive on this matter (Curtice and Holmberg 2005; Karvonen 2010; Holmberg and Oscarsson 2011; Garzia 2014).

A parallel strand of research has tackled the "conditionality" of leader effects (Barisione 2009; Mughan 2015) either by looking into the institutional design of political systems, the features of political parties or the voters' individual characteristics. While the role of political leaders is structurally enhanced in majoritarian and presidential regimes, many contributions point to the increased importance of political leaders on voting behavior in parliamentary democracies as well (Curtice and Lisi 2014). In this context, the role of the evaluation of leaders was shown not only to influence vote choice, but also electoral turnout (Silva, 2018; Silva and Costa 2019; Silva et al. 2019). Moreover, leader effects can vary significantly across party types, leading to new questions about which underlying conditions produce this heterogeneity. Indeed, political leadership is particularly significant for the electoral success of "catch-all parties" (Lobo 2008). However, the electoral success of party leaders also depends on voters' individual characteristics. As Aaldering shows (2018), political leaders do not conceal the role of ideological and issue-oriented preferences, although leader effects are particularly influential for voters lacking a keen interest in politics.

Remarkably, research on the conditionality of leader effects has largely overlooked the populist radical right. To the best of our knowledge, no long-term comparative analysis has yet tested the "leader effect hypothesis" that leader evaluations influence the populist radical right vote, and how this effect compares with that of ideological preferences and other vote choices. Evidence of the significance of leader effects for voting for populist radical right parties is meager. For instance, van der Brug and Mughan (2007) find little support for what they label the "charismatic leadership hypothesis" of voter support, which is actually measured by leader thermometer scores. However, some existing single- 
country studies find leader evaluation to be significantly associated to populist radical right vote - even more strongly than other political characteristics (Schumacher and Rooduijn 2013, Kestila-Kekkonnen and Söderlung 2014). In a country-level analysis, Aardal and Binder (2011) find no significant leader effect for the populist radical right vote. This latter study looks at nine countries between 1970 and roughly 2000 (i.e. Australia, Canada, Germany, the Netherlands, Norway, Spain, Sweden, the United Kingdom, and the United States). Incidentally, there were only two populist radical right parties in two of these countries over that time span, which casts doubts on the external validity of these results (the presence of Norwegian Fremskrittspartiet and Swedish $N y$ Demokrati makes up for seven out of the 265 elections they consider). While the few existing studies on leader effects remain inconclusive, the populist radical right scholarship keeps pointing to the decisive role of leaders in explaining these parties' success. Generally, this research strand considers that "the charismatic bond between leader and follower is absolutely central to populist parties" (Albertazzi and McDonnell 2008: 7).

Bridging these two research fields provides compelling incentives to reexamine the influence of party leaders on the populist radical right vote. Given the findings that leader effects influence vote choice; and that, minimally, populist radical right leaders are as prominent as other party leaders, we derive our first general hypothesis on the influence of leader evaluations on the vote for populist radical right parties:

H1: Voters' evaluation of party leaders is significantly associated with voting for populist radical right parties.

Further, research on populist radical right's leaders points to their specific function within the party: more than being just the face of the party, they are claimed to "have the ability to project themselves as the embodiment of the party/politics" (Eatwell 2002: 19). In light of the specific relation of embodiment of the populist radical right parties by their leaders, we can derive two subsequent hypotheses on the relative importance of leader effects for the populist radical right vote. Following the idea that populist radical right leaders embody the party's politics, we can hypothesize that leader effects are more important for its voters than other long-term drivers of party support. In particular, we hypothesize that :

$\mathrm{H}$ 2: Leader evaluations are more important than left-right self-placement when it comes to voting for the populist radical right.

Finally, populist radical right leaders are often considered to try and demarcate themselves from other leader of mainstream parties and entertain a privileged relation to their voters (Heinisch 2003). Consequently, populist radical right leaders exert a specific appeal to some voters - which goes beyond the conventional influence of other party leaders (Eatwell 2018). Given how populist radical right leaders tend to personify vote choice (Eatwell 2002), we also hypothesize that:

H3: Leader effects are more important for populist radical right voters than for other voters.

\section{Data and Operationalization}

Advocates of the link between personalization and the populist radical right vote often rely on common wisdom arguments, normative reasoning or, at best, on country- (or even case-) specific evidence. The lack of long-term comparative assessments results largely from 
data scarcity, or from the demanding data harmonization effort required to tackle this question. In this paper, we assess the relevance of leader effects on the populist radical right vote through an original pooled dataset including 29 National Election Studies from ten Western European parliamentary democracies conducted in the period 1985-2018. This dataset includes all available National Election Studies featuring the populist radical right vote (our dependent variable) and leader evaluations as a covariate. National Election Studies offer several advantages compared to other cross-sectional comparative surveys. First, they simultaneously feature comparable measures across countries for our key covariates of interest (i.e., leader evaluations, party identification, and ideology). Second, they include measures that are necessary to estimate fully specified models of vote choice for radical right parties (i.e., items tapping political interest, trust and attitudes towards immigration) which are not available in existing cross-national projects (e.g., CSES).

van der Brug and Mughan's (2007) analysis of the Dutch case is a pioneering empirical study of leader effects and the populist radical right vote. However, this contribution faces empirical limitations, which the present analysis aims to overcome. Indeed, their analysis is not comparative and considers a very limited timespan (i.e., three elections held in less than a decade), which undermines the generalizability of the validity of the findings beyond the peculiar, extreme multi-party case of the Netherlands. Moving beyond existing case studies (Schumacher and Rooduijn 2013; Kestila-Kekkonnen and Söderlung 2014), comparative empirical analyses of leader effects for different party families tend to overlook populist radical right parties (Lobo 2008; Garzia 2014). This paper expands the scope of the analysis in a comparative perspective, in terms of time and countries. The selection of countries and National Elections Studies relies on several criteria. First, we consider countries and elections in which there is a sizeable populist radical right party (we set the threshold for electoral relevance at $3 \%$ of the votes). ${ }^{3}$ To ensure the consistency of our case selection, we only consider parties labeled as populist radical right parties in the peer-reviewed The PopuList dataset (Rooduijn et al. 2019). As candidates and party leaders have always been pivotal in presidential systems, we restrict our sample to parliamentary democracies, in view of a more demanding test of our hypothesis. Among these countries, we only included the studies featuring party leader evaluations, left-right self-placement and party identification, as they are key independent variables in our vote choice models. The focus of the paper is on Western Europe, because of its longer experience with democratic elections, and more stable and comparable party systems. Populist radical right parties in Central and Eastern Europe are electorally successful, but they are also less stable over time, tend to compete on different issues, and have very different political origins (for a discussion on the need to study Western European and Central and Eastern European populist radical right parties separately, see Pirro 2015). Additionally, National Election Studies provide only limited longitudinal data for Central and Eastern Europe. Table 1 summarizes the countries, elections, and the populist radical

\footnotetext{
${ }^{3}$ Populist radical right parties form a heterogeneous party family - although variance within this party family is arguably not larger than in other mainstream party families. In this paper, we define membership to a party family based on ideological, electoral, and organizational criteria (Poguntke 1987). Populist radical right parties share a nativist ideology, that is "an ideology, which holds that states should be inhabited exclusively by members of the native group ("the nation") and that nonnative elements (persons and ideas) are fundamentally threatening to the homogenous nation -state" (Mudde 2007: 19). An additional confirmation of the coherence of the populist radical right family is that these parties share a pattern of voter mobilization: immigration grievances are central to these voters (Arzheimer 2008; Ivarsfalten 2008, Inglehart and Norris, 2017). Moreover, populist radical right parties share organizational features such as hierarchy and membership patterns (Heinisch and Mazzoleni, 2016).
} 
Table 1: Elections Included in the Analysis

\begin{tabular}{llcl}
\hline Country & \multicolumn{1}{c}{ Period } & Time Points & \multicolumn{1}{c}{ Populist Radical Right Party } \\
\hline Austria & $(2013)$ & 1 & Freiheitliche Partei Österreichs (FPÖ) \\
Denmark & $(2001-2005)$ & 2 & Dansk Folkeparti (DF) \\
Finland & $(2007-2015)$ & 3 & Perussuomalaiset (PS) \\
Greece & $(2012)$ & 1 & Chrysi Avgi (XA) \\
Italy & $(1996-2018)$ & 5 & Lega Nord (LN) \\
Netherlands & $(1998-2010)$ & 4 & Centrum Democraten (CD) \\
& & & Lijst Pim Fortuyn (LPF) \\
Norway & $(1985-2013)$ & 8 & Partij voor de Vrijheid (PVV) \\
Sweden & $(2010)$ & 1 & Fremskrittpartiet (FrP) \\
Switzerland & $(2007-2015)$ & 3 & Schwedemokraterna (SD) \\
United Kingdom & $(2015)$ & 1 & United Kingdom Independence Party (UKIP) \\
\hline
\end{tabular}

Note: For detailed references of the National Election Studies included in our analysis, see Appendix A.

right parties included in this analysis (see Appendix A for the complete list of National Election Studies included).

We are interested in measuring leader effects on the populist radical right vote, i.e. how well party leaders' evaluation predicts electoral support for populist radical right parties. In the following analyses, the dependent variable is therefore vote choice, valued ' 1 ' if respondents voted for a populist radical right party and ' 0 ' if they voted for any other party (abstainers are thus excluded from the analyses).

We measure leader evaluations through feeling thermometers, i.e. the affective score attributed to a given political leader by survey respondents. In our dataset, we have standardized leader evaluation throughout the 29 National Election Studies on a 11-point thermometer scale (see Appendix B for question wording of leader thermometer question and recoding strategy when appropriate ${ }^{4}$ ). We therefore follow van der Brug and Mughan's approach of assessing leaders influence with thermometer scores, largely expanding their study (2007). Substantially, thermometer scores have the advantage of not relying on previously defined individual characteristics of political leaders (such as mediasavviness, orator skills, personality, etc.), and they offer a general assessment of how voters perceive political leaders. Additionally, thermometer scores are widely available in National Election Studies, which is not the case of leaders' personality traits (Bittner 2011). ${ }^{5}$

\footnotetext{
${ }^{4}$ The Selects datasets for Switzerland do not include exactly the evaluation of "party leaders" but rather that of "political personalities". As one political personality is tested for each of the main parties of Switzerland, we consider them to be the functional equivalent of party leaders - particularly the questionnaire consistently asks about the historical leader (Blocher) of the populist radical right party (SVP). As shown in the robustness tests below, the inclusion/exclusion of Switzerland in our analysis does not change the results.

${ }^{5}$ Most of the studies included in our pooled dataset ask respondents to score leaders on a like-dislike scale. The Danish studies use very bad-very good scales; the Italian studies use totally negative-totally positive scales, and both the Dutch and the Swiss studies use very unsympathetic-very sympathetic scales. Previous studies attest the measurement equivalence across these different scales, which elicit "an overall summary judgement about each leader" (Curtice and Holmberg 2005: 238). This is particularly common across comparative longitudinal projects: the same approach was employed in The European Voter project (Thomassen 2005).
} 
We build our predictive models of the radical right vote relying on existing literature and include the most significant drivers of this vote. We consider three sets of conventional predictors of vote choice in our analysis. First, we include socio-demographic variables: age (in years), gender (binary, $0=$ man, $1=$ woman), educational attainment (recoded on a 3-point scale: 1=Primary/ISCED categories $0-2 ; 2=$ Secondary/ISCED levels 3-4, and 3=Tertiary/ISCED levels 5-8; see UNESCO Institute for Statistics 2011), religiousness (from $0=$ 'not at all religious' to $3=$ 'very religious') and union membership ( 1 = member of a union, 0 otherwise). Second, we include respondents' ideological positions, measured with left-right self-placement (ranging from 0 "Left" to 10 "Right"), and the extent to which they feel close to the populist radical right ( 4-point scale, $0=$ "respondent is not close to the party", 1 = "only sympathizers", 2 = "fairly close", and $3=$ "very close"). ${ }^{6}$

Finally, we are able to include a set of three specific attitudes directly associated to the populist radical right vote. According to established findings, attitudes towards immigration, political discontent, and economic grievances are associated with the populist radical right vote (Betz 1994). As a matter of fact, the perception of "ethnic threat", i.e., the fear of the consequences of immigration, and "political distrust" have been shown to be the most important attitudinal factors fueling the populist radical right vote (Werts et al. 2013). Indeed, the populist radical right vote is largely driven by socio-cultural attitudes, i.e., law and order, traditional morality, or national way of life (Mudde and Rovira Kaltwasser 2018). Populist radical right parties tend to mobilize their voters mainly on the issue of immigration (Rydgren 2005, 2007). However, attitudes towards migration are multifaceted and can be measured in diverse ways (Ceobanu and Escandell 2010). National Election Studies resort to a variety of questions to measure attitudes towards immigration. We solve the conundrum of defining consistent measures of preferences on immigration by taking the political salience of immigration attributed by voters as a proxy. Issue salience is an established and influential factor of party competition. Indeed, the salience of an issue is a critical determinant of vote choice - especially for a given issue a party is considered to "own" (Budge and Farlie 1983; Petrocik 1996). In the case of immigration, we assume that position can be inferred from salience, as immigration is politicized largely negatively, and radical right populist parties are considered the owners of the issue (van der Brug 2004; van der Brug et al. 2015). We therefore use the dichotomous variable "rating immigration as the most important issue" $(=1$, other issues $=0)$ as a proxy for the position on immigration. While acknowledging that salience and preferences on immigration are different at the individual level, we contend that "if salience and preference are highly correlated, then

\footnotetext{
${ }^{6}$ Originally designed to study the American two-party system, the conceptual validity of party identification in the West European context has been object of a long intellectual debate (Budge et al. 1976; Bartle and Bellucci 2009; Garzia and De Angelis 2016). Some studies even challenged its applicability to multi-party systems insofar as party identification appeared "indistinguishable" from vote choice (Thomassen 1976; Thomassen and Rosema 2009). Accordingly, Rosema (2006) suggests that an attitudinal conceptualisation of partisanship may be more appropriate. Such view is indeed adopted by virtually all national election studies conducted across Europe, which employ question wording tapping closeness to a party rather than identification with it. On these bases, our analyses rely on a minimal definition of partisanship, defined as "a long term tendency to support a party rather than another" (Bartle and Bellucci 2009: 1).
} 
preference for or against immigration (or salience in the present case of this paper) might be sufficient as a "thermostat of public opinion"” (Hatton 2017: 20). ${ }^{7}$

Additionally, political discontent is associated to the populist radical right vote (van Hauwaert and van Kessel 2018). We therefore account for the specific effect of political distrust on the populist radical right vote, which we measure with an indicator of trust in political parties on a scale between 0 and 10 (following Ivarsflaten 2008).

Another strand of research considers the radical right voters to be the 'losers of globalization', in both socio-cultural and economic terms (Kriesi et al. 2012). While attitudes towards immigration often serve as an indicator for socio-cultural attitudes, we also consider socio-economic grievance. Indeed, voters' economic grievances also explain support for the populist radical right (Derks 2006). We therefore account for individual retrospective perception of the economy (3-point scale, $1=$ 'the respondent's situation has worsened', 2 = 'it has stayed the same', and 3 ='it has improved').

Lastly, as leader effects may additionally depend on voters' ability and motivation to process political information, we do not only control for levels of education achievement, but also for interest in politics (4-point scale from $1=$ "not interested at all" to $4=$ "very interested") (see Appendix C for summary statistics of all variables included in our analysis).

The next sections present the empirical tests of the relevance of leader effects on voting for the populist radical right. We start by presenting bivariate evidence on party leader evaluations for different parties in Western Europe. Moving to a multivariate analysis, in a first step, we assess the importance of leader evaluations in explaining the populist radical right vote while controlling for a number of relevant variables $(\mathrm{H} 1)$. Through a variety of post-estimation procedures, we subsequently compare the relative effect of leader thermometers vis-à-vis strength of party closeness and left-right proximity for the populist radical right vote $(\mathrm{H} 2)$. In the last stage, we measure and compare leader effects between populist radical right voters and all other voters (H3). We conclude with a series of robustness tests aimed at verifying the reliability of the results.

\section{Populist Radical Right Leader Evaluation and Leader Effects}

As a preliminary step to assess leader effects on the populist radical right vote, we compare how voters evaluate party leaders. Table 2 presents the average thermometer score of populist radical right leaders, as assigned by their voters, compared to the average score assigned by voters of other party families to their parties' respective leader. ${ }^{8}$ In all cases, voters tend to evaluate the leader of the party for which they voted positively (average score between 5.83 and 9.33 on an 11-point scale). From these descriptive results, we cannot conclude that populist radical right leaders are better evaluated by their voters

\footnotetext{
${ }^{7}$ In our dataset, the pairwise correlation between voting for the radical right and salience of immigration at the individual level is $.21(p<.001)$. Appendix D shows the distribution of the populist radical right vote and the perception of immigration as the most important issue.

${ }^{8}$ We consider the leader of six other main party families in Western Europe: (Post)-Communist Left, Socialist/ Social-Democrats, New Left (Greens), Liberals, Christian-Democrats, Conservatives. Including the populist radical right, these seven party families encompass almost every party competing in Western Europe. Our classification divides the parties of the mainstream right into two categories (Conservatives and Christian Democrats) to be able to account all competing party leaders. See Appendix E for full list of parties considered, their leaders, and the respective mean leader evaluation score across all respondents, and Appendix F for every mean leader evaluation among the respective voters.
} 
Table 2: Leader Evaluation of Populist Radical Right and Other Party Leaders

\begin{tabular}{|c|c|c|c|c|c|c|}
\hline Election & Leader & Mean & s.d. & Missing (\%) & $\%>5$ & Difference \\
\hline \multirow[t]{2}{*}{ Austria 2013} & Strache & 5.93 & 2.95 & 4.65 & 59.76 & -0.35 \\
\hline & Others & 6.28 & 2.43 & 3.85 & 64.55 & \\
\hline \multirow[t]{2}{*}{ Denmark 2001} & Kjaersgaard & 7.70 & 2.27 & 0.49 & 80.79 & +0.08 \\
\hline & Others & 7.62 & 1.98 & 0.65 & 85.45 & \\
\hline \multirow[t]{2}{*}{ Denmark 2005} & Kjaersgaard & 7.92 & 2.06 & 0.00 & 88.57 & $+0.53 * * *$ \\
\hline & Others & 7.39 & 2.10 & 0.83 & 81.49 & \\
\hline \multirow[t]{2}{*}{ Finland 2007} & Soini & 8.25 & 1.64 & 0.00 & 90.62 & $+0.93 * * *$ \\
\hline & Others & 7.32 & 2.07 & 1.98 & 83.33 & \\
\hline \multirow[t]{2}{*}{ Finland 2011} & Soini & 7.79 & 1.89 & 0.54 & 85.79 & $+0.37 * *$ \\
\hline & Others & 7.42 & 2.03 & 1.20 & 85.79 & \\
\hline \multirow[t]{2}{*}{ Finland 2015} & Soini & 7.53 & 1.73 & 0.51 & 83.76 & $+0.31 * *$ \\
\hline & Others & 7.22 & 2.04 & 3.28 & 80.00 & \\
\hline \multirow[t]{2}{*}{ Greece 2012} & Michaloliakos & 6.63 & 2.46 & 0.00 & 78.95 & -0.11 \\
\hline & Others & 6.74 & 2.64 & 0.99 & 71.06 & \\
\hline \multirow[t]{2}{*}{ Italy 1996} & Bossi & 7.51 & 2.00 & 0.63 & 91.72 & $-0.37 * * *$ \\
\hline & Others & 7.88 & 1.71 & 0.82 & 93.94 & \\
\hline \multirow[t]{2}{*}{ Italy 2001} & Bossi & 7.28 & 2.31 & 1.85 & 86.79 & $-0.54 * *$ \\
\hline & Others & 7.82 & 1.93 & 9.01 & 92.60 & \\
\hline \multirow[t]{2}{*}{ Italy 2006} & Bossi & 7.61 & 1.80 & 0.00 & 91.18 & -0.08 \\
\hline & Others & 7.69 & 1.97 & 1.72 & 91.23 & \\
\hline \multirow[t]{2}{*}{ Italy 2013} & Maroni & 6.09 & 1.63 & 0.00 & 72.73 & -0.27 \\
\hline & Others & 6.36 & 2.02 & 3.70 & 69.46 & \\
\hline \multirow[t]{2}{*}{ Italy 2018} & Salvini & 7.85 & 2.06 & 2.34 & 88.00 & $+1.89 * * *$ \\
\hline & Others & 5.96 & 2.44 & 1.78 & 62.44 & \\
\hline \multirow[t]{2}{*}{ Netherlands 1998} & Janmaat & 9.33 & 1.15 & 0.00 & 100.00 & $+1.89 * *$ \\
\hline & Others & 7.44 & 1.71 & 5.08 & 86.39 & \\
\hline \multirow[t]{2}{*}{ Netherlands 2002} & Fortuyn & 7.57 & 2.16 & 0.62 & 85.09 & $+0.38 * * *$ \\
\hline & Others & 7.19 & 1.78 & 0.87 & 86.26 & \\
\hline \multirow[t]{2}{*}{ Netherlands 2006} & Wilders & 7.58 & 1.35 & 9.92 & 94.50 & -0.08 \\
\hline & Others & 7.66 & 1.22 & 6.59 & 95.60 & \\
\hline \multirow[t]{2}{*}{ Netherlands 2010} & Wilders & 6.15 & 2.27 & 4.15 & 66.23 & $-1.20 * * *$ \\
\hline & Others & 7.35 & 1.48 & 10.95 & 89.30 & \\
\hline \multirow{2}{*}{ Norway 1985} & Hagen & 8.26 & 1.81 & 1.52 & 89.23 & +0.18 \\
\hline & Others & 8.09 & 1.69 & 2.66 & 91.24 & \\
\hline \multirow[t]{2}{*}{ Norway 1989} & Hagen & 8.36 & 1.52 & 0.49 & 93.66 & $+0.76 * * *$ \\
\hline & Others & 7.60 & 1.85 & 1.48 & 85.64 & \\
\hline \multirow[t]{2}{*}{ Norway 1993} & Hagen & 8.02 & 1.42 & 1.22 & 97.53 & +0.32 \\
\hline & Others & 7.70 & 1.80 & 1.87 & 89.13 & \\
\hline \multirow[t]{2}{*}{ Norway 1997} & Hagen & 8.01 & 1.58 & 0.52 & 93.19 & $+0.75 * * *$ \\
\hline & Others & 7.26 & 1.97 & 0.89 & 80.75 & \\
\hline \multirow[t]{2}{*}{ Norway 2001} & Hagen & 8.41 & 1.29 & 0.53 & 97.85 & $+1.73^{* * *}$ \\
\hline & Others & 6.68 & 2.02 & 0.86 & 72.12 & \\
\hline Norway 2005 & Hagen & 8.13 & 1.62 & 0.00 & 93.92 & $+0.36 * * *$ \\
\hline & Others & 7.77 & 1.70 & 0.40 & 90.31 & \\
\hline Norway 2009 & Jensen & 8.13 & 1.65 & 1.01 & 91.16 & +0.15 \\
\hline & Others & 7.98 & 1.54 & 0.45 & 92.75 & \\
\hline Norway 2013 & Jensen & 7.68 & 1.73 & 2.79 & 88.51 & $-0.52 * * *$ \\
\hline & Others & 8.20 & 1.42 & 0.71 & 95.01 & \\
\hline
\end{tabular}


Table 2: Continued

\begin{tabular}{llccccc}
\hline Election & Leader & Mean & s.d. & Missing $(\%)$ & $\%>5$ & Difference \\
\hline Sweden 2010 & Akesson & 7.23 & 2.18 & 28.57 & 73.85 & $\mathbf{- 0 . 6 7 * * *}$ \\
\multirow{2}{*}{ Switzerland 2007 } & Others & 7.90 & 1.96 & 24.20 & 87.45 & \\
& Blocher & 8.27 & 1.88 & 0.42 & 90.45 & $\mathbf{+ 1 . 1 3 * * *}$ \\
Switzerland 2011 & Others & 7.14 & 2.53 & 2.11 & 75.91 & \\
& Blocher & 6.77 & 2.64 & 0.72 & 71.30 & $\mathbf{- 0 . 6 1 * * *}$ \\
Switzerland 2015 & Others & 7.38 & 2.10 & 3.40 & 80.20 & \\
\multirow{2}{*}{ United Kingdom 2015 } & Blocher & 6.62 & 2.81 & 3.86 & 66.71 & $\mathbf{- 1 . 0 8 * * *}$ \\
& Others & 7.7 & 2.09 & 5.56 & 85.27 & \\
& Farrage & 7.26 & 2.13 & 1.71 & 79.57 & $\mathbf{+ 0 . 9 1 * * *}$ \\
& Others & 6.35 & 2.27 & 2.07 & 68.08 & \\
\hline
\end{tabular}

Note: $* p<0.05, * * p<0.01, * * * p<0.00$.

than other candidates by their respective constituents. Populist radical right leaders are significantly better evaluated in 13 cases out of 29 (last column in Table 2 presents the difference and significance of t-tests), but significantly evaluated less positively then other party leaders in seven cases.

The descriptive results of Table 2 do not show clear-cut differences in leader evaluations between populist radical right voters and other voters. However, some populist radical right leaders seem to be substantially better evaluated by their voters than other party leaders, especially when they are longstanding party leader (e.g. Timo Soini of the Finnish PS, or Carl Hagen of the Norwegian FrP). On the other hand, we can observe the effects of a specific leader on populist radical right voters: in four out of five cases (1996-2013), voters of the Italian Lega did not evaluate the leader of their party better than other party voters did. Yet, in 2018, voters of Lega better evaluate Matteo Salvini than any other voters evaluated their leader in our sample. Still, apart from these specific configurations, we do not find that voters of the populist radical right substantially evaluate their party better leader than other voters do.

In order to assess to what extent leader evaluations actually relate to voting for the populist radical right, we thus resort to multivariate regression analysis. This is a required step to rule out the patterns of correlation (and potential overlap) between some key variables of interest. Following Holmberg and Oscarsson's (2011) large-N analysis of vote choice in 10 European countries, we opt for a conservative approach, and therefore include a wide range of statistical controls that may be somehow interrelated. Indeed, the objective is to find an "independent" effect of leader evaluations on the vote, irrespective of other factors. The inclusion of an extended array of controls may result in an underestimation of leader effects (compared to previous studies relying on uncontrolled or raw leader effects), yet we believe this conservative approach yields safer results.

We estimate hierarchical multilevel logistic regressions that include a random-intercept at the election level to control for unobserved heterogeneity across countries and over time within-country. We fit six successive models to predict the populist radical right vote. After assessing the raw effect of leader evaluation on the populist radical right vote (Model 1), the models incrementally include variables in the logic of the 'funnel of causality' (Campbell et al. 1960). First, we include the effects of socio-demographics and interest in politics (Model 2). Second, the model accounts for the long-term drivers of 
party choice (left-right self-placement and strength of partisanship; Model 3). Finally, we add short-term political evaluations and party-specific drivers of the populist radical right vote (retrospective perception of the economy, position on immigration and trust in political parties; Models 4, 5, and 6 respectively).

The estimates lend support to the hypothesis that leader evaluations have a positive and significant effect on voting for the populist radical right in Western Europe across all models. Our estimates confirm that populist radical right voters tend to be disproportionately men $^{9}$, and confirms the negative effect of education and political interest (Rydgren 2007; Zhirkov 2014). Strength of partisanship and ideological selfplacements on the right side of the spectrum are also associated to voting for the populist radical right. However, taking into account partisanship and ideology only marginally affects the leader effect on the populist radical right vote. We also note that the statistical impact of left-right self-placement is moderate compared to that of leader evaluation (both variables are measured on a 0-10 scale).

Introducing issue specific variables, we find in Model 4 that voters of the populist radical right also have a generally negative perception of the economy, supporting the findings on the effects of economic crises and hardship on populist radical right support (Hernandez and Kriesi 2018; Rama and Cordero 2018). The inclusion of the immigration variable in Model 5 provides further evidence in favor of our hypothesis. Rating immigration as the most important issue correlates significantly with voting for the radical right, and this variable significantly increases the explanatory power of our models. However, the inclusion of immigration barely influences the other estimates, and the effect of leader evaluation remains unchanged. ${ }^{10}$ In a final additive step, Model 6 includes 'trust in political parties', as a measure for political discontent. As expected, distrust in political parties is associated to the populist radical right vote. In this extended model, leader evaluations remain nonetheless a strong predictor of voting for the radical right, even controlling for long-term factors of vote choice and short-term or attitudinal factors. In addition, the fact that the effect of immigration decreases in Model 6 corroborates the recent findings that populist attitudes, such as political discontent, "moderate the effect of issue positions" on the populist radical right vote (van Hauwaert and van Kessel 2018). Because of the scattered availability of this latter item, Model 6 includes fewer National Elections Studies and cases; however, we can still conclude that there is a genuine leader effect on the populist radical right vote. The consistent and sizeable leader effect across all models of vote for populist radical right parties supports the confirmation of $\mathrm{H} 1$.

We then move to test $\mathrm{H} 2$, which assumed a stronger effect of leader evaluations, compared to left-right self-placement and party closeness, for the populist radical right vote. In order to compare their effects, we resort to predicted probabilities of voting for the populist radical right, which also allow for inspecting eventual non-linearity in the effects of these covariates (for instance, the difference in effects between not having a party identification and being a sympathizer may not be the same as the difference between being fairly close and a very strong partisan). Figure 1 shows the predicted

\footnotetext{
${ }^{9}$ Although the male/female gap in voting for the radical right strongly varies across West European countries (Immerzeel et al. 2015).

${ }^{10}$ Yet, we do not conclude on the definitive magnitude of the effect of attitudes towards immigration from these models. Indeed, we do not assume that saliency of immigration perfectly replaces measures of attitudes towards immigration, nor that all respondent who rank immigration as the most important problem support the populist radical right parties.
} 
Figure 1: Predicted Probability of Voting for the Populist Radical Right

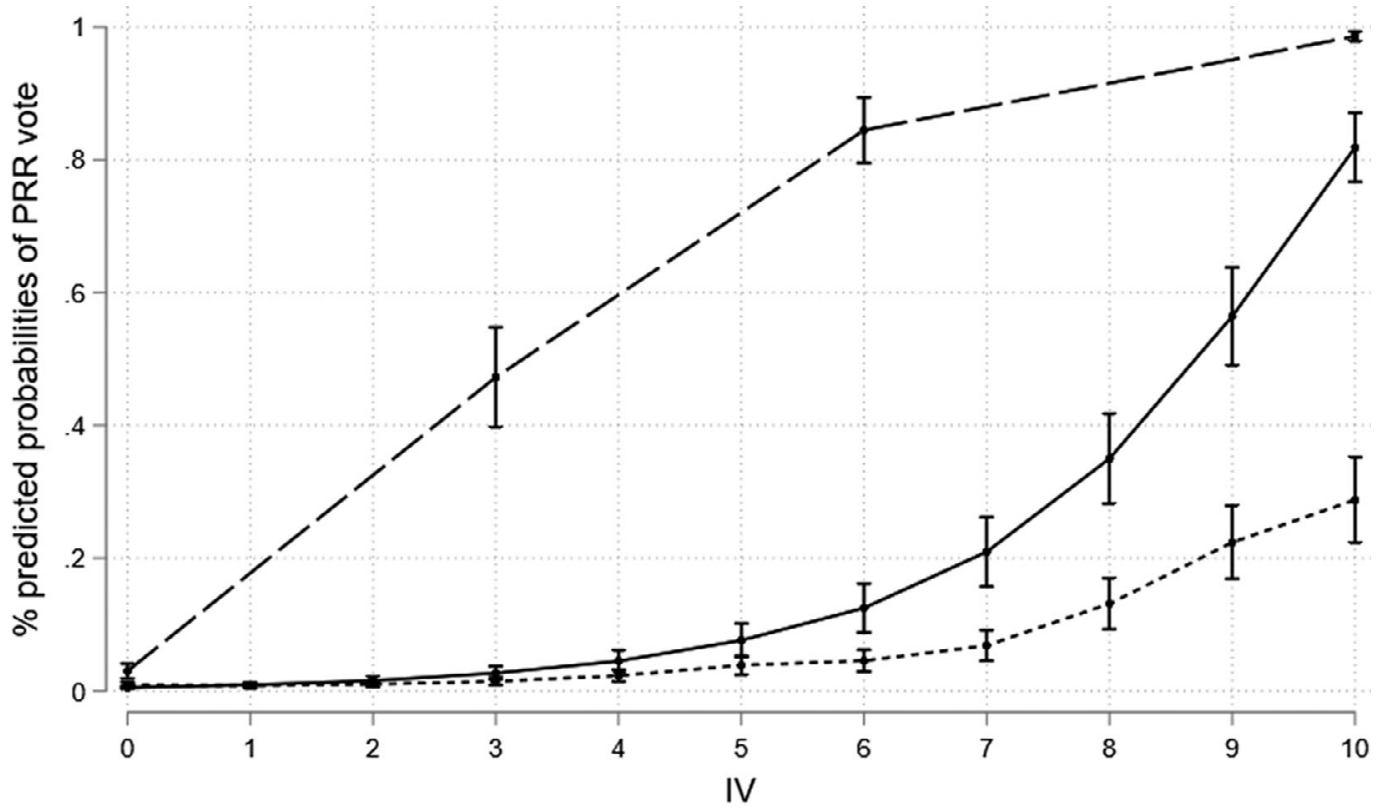

$\rightarrow$ PRR leader thermometer $\rightarrow$ Strength of party closeness $\quad \rightarrow \rightarrow$ Left-Right self-placement

probabilities of voting for the radical right across strength of party closeness (values recoded to match with the other predictors), leader thermometer, and left-right selfplacement (with all other variables set at their mean level). Voters who identify on the left of the political spectrum ( 5 and below) and who evaluate populist radical right leaders negatively ( 5 and below) have very little chance of voting for such party. The probability of voting for the populist radical right grows constantly as a voter identifies more with the right (between 5 and 10) and evaluates the party leader positively (between 5 and 10). However, the latter effect yields much higher probability of voting for the populist radical right, as one evaluates the leader better, rather than identifies more to the right. ${ }^{11}$ The effect of leaders is clearly not linear, as seen evidenced by the predicted probabilities at the positive values of the scale.

Strength of party closeness appears to be the most predictive of populist radical right vote. However, this finding should be interpreted with caution, as the predicted values may be highly dependent on extreme values which find very little translation on the data. For example, while according to the predicted probabilities "very strong partisans" of populist radical right parties are almost certain to vote for their party, these individuals amount to only about 1,5 percent of the sample. Likewise, combining "fairly strong" and "very strong partisans" - the two values with predicted probabilities above leader thermometers

\footnotetext{
${ }^{11}$ Populist radical right parties largely mobilize their voters against immigration, and we acknowledge that antiimmigration attitudes may constitute the core ideological variable in our models. We therefore also calculated predicted probabilities for that variable. Individuals who do not consider immigration to be the most salient issue have a predicted probability of voting for the populist radical right of 0.09 ; this probability is of 0.26 for individuals who consider immigration as the most salient issue. While this effect is substantial, we remain cautious in its interpretation, since our measure for immigration is imperfect.
} 
-, constitutes only about 4 percent of the whole sample. Even adding sympathizers of populist radical right parties, the proportion never exceeds 5 percent of the sample. Hence, these estimates apply to outliers in our data, and are little representative of overall populist radical right voters (14 percent of the sample). Conversely, nearly 30 percent of the sample scores populist radical right leaders positively (5 or above). These disparities may call for a reinterpretation of the more immediate conclusions one could draw from Figure 1. As discussed before, partisanship has often been found to be empirically undistinguishable from vote choice in the context of European parliamentary democracies (Rosema 2006, Thomassen and Rosema 2009), and this may even be more the case in ideologically extreme parties. Our data seems to reflect this pattern, as 96 percent of very strong populist radical right partisans vote consistently with their partisanship, as do 92 percent of fairly close partisans and 86 percent of sympathizers. Thus, paradoxically, while strength of partisanship is indeed the strongest predictor of vote for the populist radical right, it is only able to account for very little of the votes cast for these parties.

For these reasons, a better strategy to compare the relative effect of these three predictors is to analyze their average marginal effects resorting to standardized estimates. By standardizing the variables, we measure their respective impact on the vote by one standard deviation changes in the independent variable. Not only does this allow to directly compare variables measured on different scales, it also reduces the bias caused by extreme categories in the overall comparison, as previously noted. Figure 2 displays the average marginal effects of all standardized variables, based on the estimates from Model 6 , Table 3. The results show that the average marginal effect of the leader thermometer for populist radical right leaders is stronger than left-right self-placement. Notably, the

Figure 2: The Correlates of Populist Radical Right Support (Average Marginal Effects)

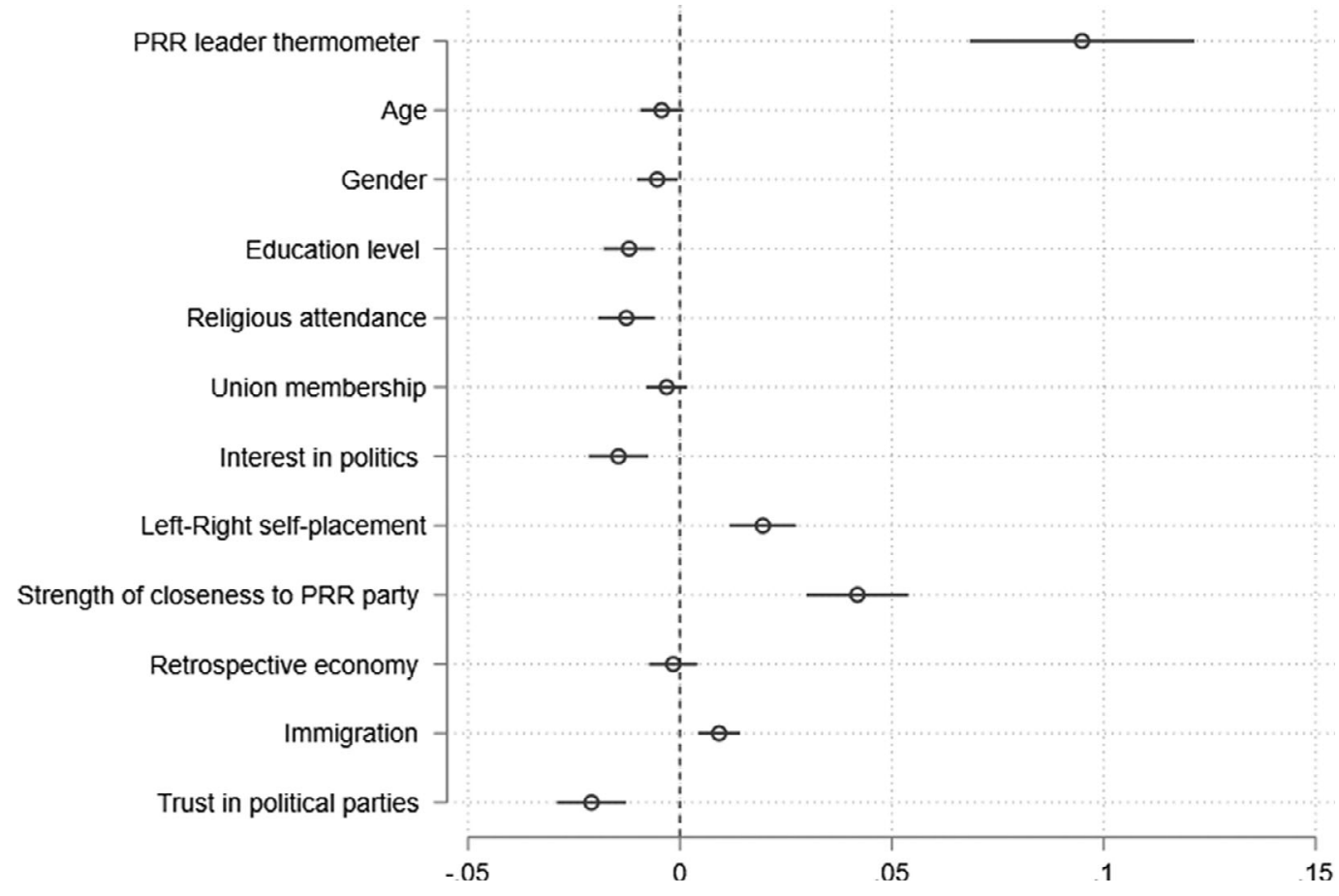


average marginal effect of the populist radical right leader thermometer is also twice as large as the one of strength of closeness to a such party. Thermometer scores of populist radical right leaders distinctly have the strongest effect on the vote for these parties, thus confirming $\mathrm{H} 2$.

\section{Leader Effects Across Party Families}

The results from the previous models confirm that leader effects impact the populist radical right's vote in Western Europe. More specifically, we show that liking a populist leader makes voters significantly more likely to vote for his or her own party - net of a wide range of socio-structural and attitudinal controls. However, these results do not imply that leader effects are stronger among populist radical right voters than for voters of other parties. By dichotomizing the dependent variable into votes for the radical right vs. all other parties, our initial approach did not allow for such comparison. In fact, leaders may be important for the voters of the populist radical right, but they may also matter (more) for the voters of other parties. To ascertain this possibility, we need a model specification that produces estimations for both categories of voters. For this reason, we restructured the dataset into a stacked data matrix by reshaping the data 'wide to long' to achieve observations defined at the individual*party level (following an established procedure in electoral research, see van der Eijk et al. 2006). With this transformation of the dataset, we avoid the pitfalls of a categorical dependent variable and opt for series of binary choices of voting for each party (0: did not vote for this party; 1: voted for this party). We compare across a total of seven party families, widely representative of political alternatives across European party systems: New Left, (Post-)Communist, Social Democrat, Conservative, Christian-Democrat, Liberal and Populist Radical Right. This 'long' data configuration is repeated as many times per respondent as the total number of party families present in each given election. This way, we can jointly consider in the analysis vote choices for all available party families- as well the evaluation of all party leaders running in a given election. We restrict the analysis to the variables defined at the individual*party level: leader evaluations (11-point scale), left-right proximity (absolute valued difference between respondent's self-placement on a 11-point left-right scale and the position assigned to each of the parties on the same scale), and strength of closeness to a political party (four categories). We compare the effect of leader evaluations for populist radical right voters and for all other voters by means of split-sample analysis. Two separate conditional logistic regression models estimate the effect of our key covariates among populist radical right voters and all other party voters respectively. The results are presented in Figure 3 by means of average marginal effects. The variables were standardized so as to allow for direct comparability of their relative impact on the vote. Full model estimates are available in Appendix G.

The disproportionate importance of leaders in explaining the radical right vote becomes more evident once we concentrate on the two remaining predictors. Strength of partisanship and left-right proximity are substantially more important to explain the vote for the remaining party families than they are for populist radical right parties. Whereas in the remaining party families the three predictors have comparable effects, leader effects have an over two-fold effect vis-à-vis the other predictors for populist radical right voters. For voters of these parties, leader evaluations assume a preeminent role in guiding voting decisions. These results provide evidence in favor of confirming $\mathrm{H} 3$. 


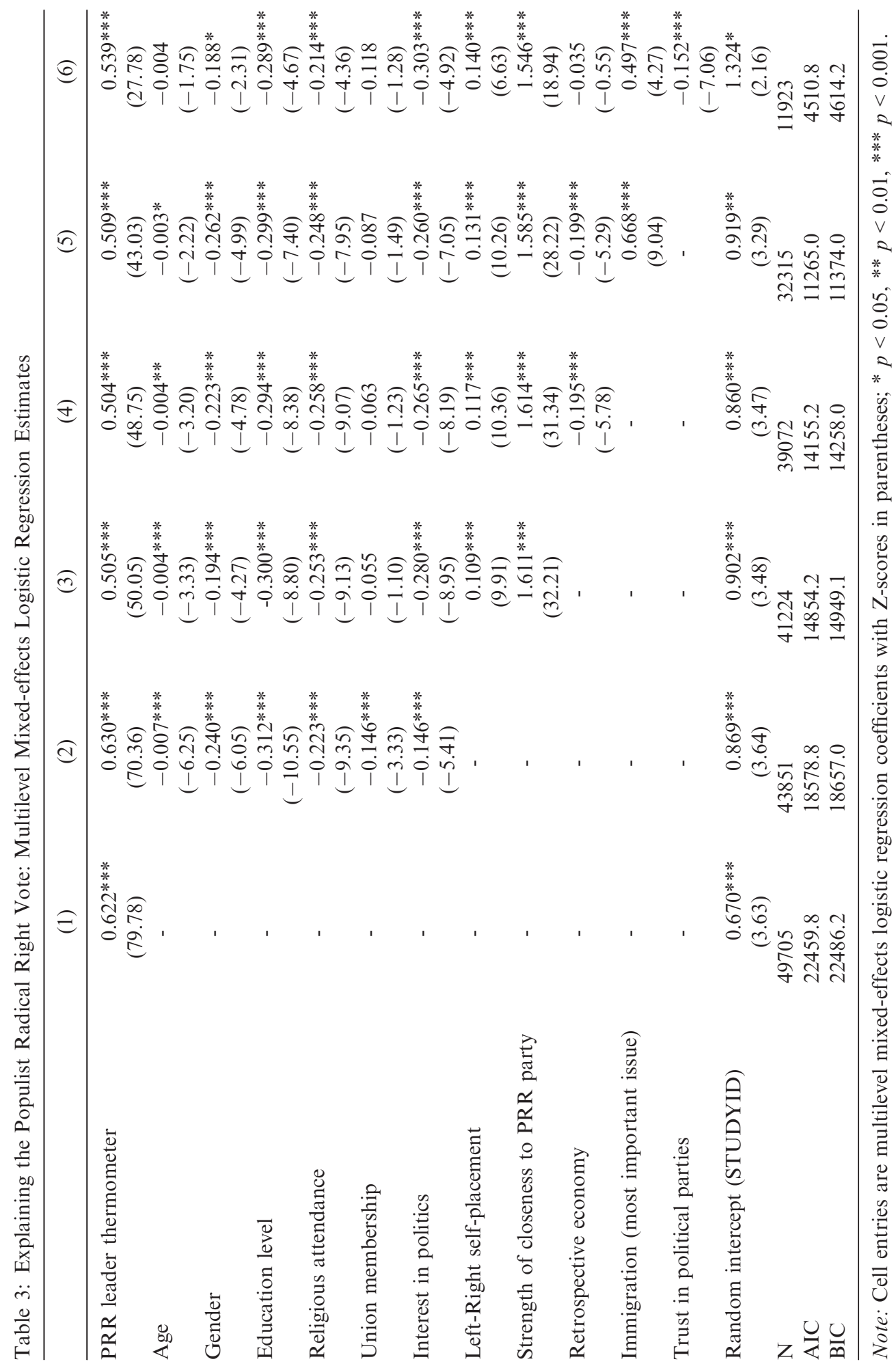


Figure 3: The Relative Effect of Left-Right Proximity, Partisanship and Leader Evaluations: Populist Radical Right Voters vs. All Other Voters (Average Marginal Effects)

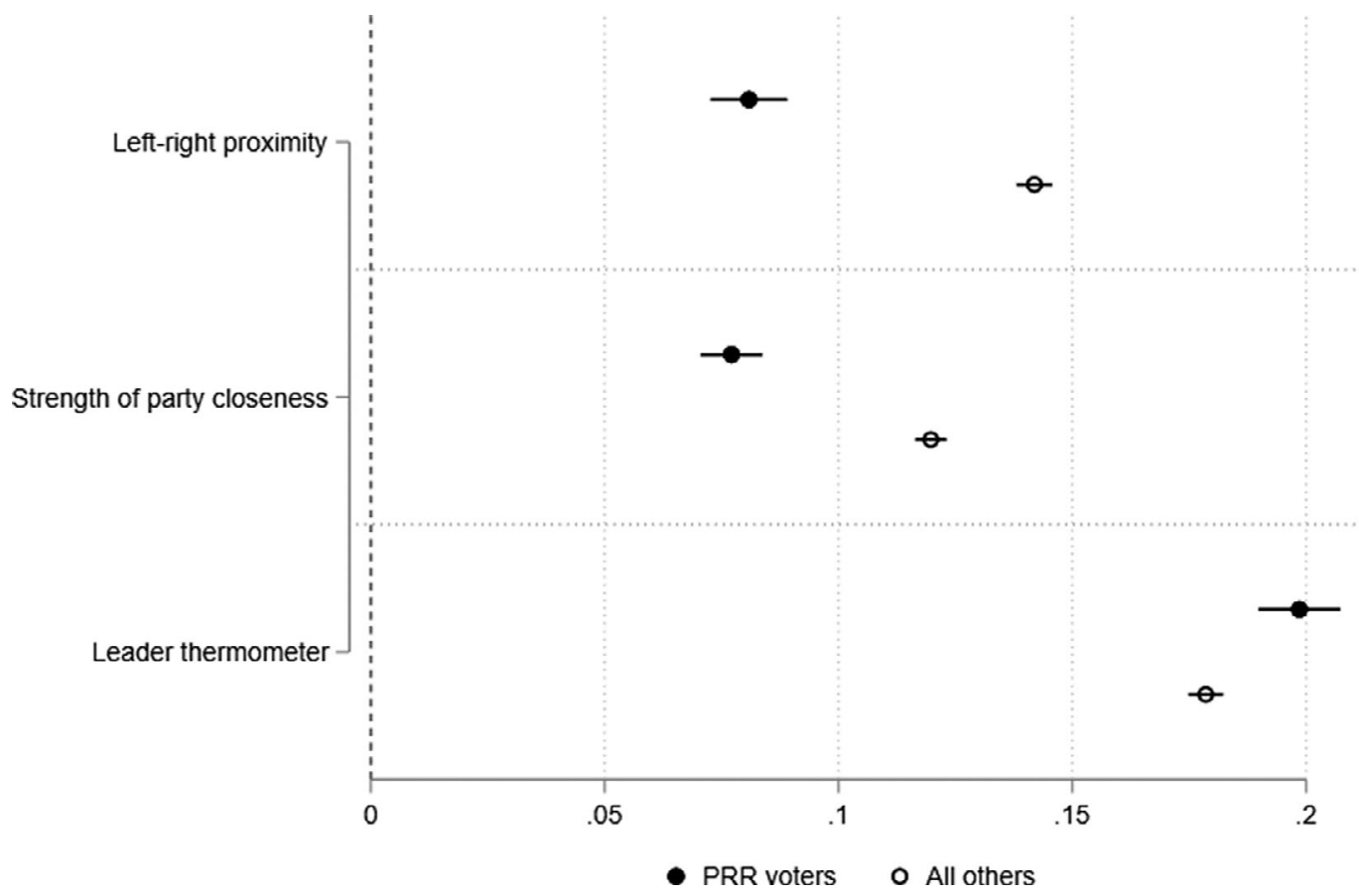

\section{Robustness}

In order to test the robustness of these findings, we resort to 'Leave-One-Out CrossValidation' (LOOCV). First, we excluded individual election studies one after the other from the sample, to inspect if an outlier could be driving the trend; this test resulted in no difference. Second, we carried a more demanding test, by repeating a similar procedure, but excluding one country at a time from the sample and re-estimating the marginal effects. We fit these robustness tests for all our statistical models. Theses sensitivity tests are presented in Appendix $\mathrm{H}$, and show that no outlier country (or populist radical right party) is driving the results. Third, we control for country specific omitted factors by estimating the conditional logistic models for each country separately. The plot in Appendix I converges with the prior findings that leader evaluations by and large matter more than ideological proximity and party identification for populist radical right voters.

\section{Conclusion}

In this paper, we bridge two strands of literature that had remained largely disconnected so far: research on leader effects on voting behavior, and research on the leaders of populist radical right parties. The populist radical right scholarship insists on the central role of the charismatic leaders, notably to explain its electoral success. On the other hand, the personalization of politics literature had not convincingly shown that leader evaluation was significant in explaining the vote for this specific party family, though it extensively documented the impact of leader evaluations on overreaching individual-level patterns of 
voting behavior (Bittner 2011; Lobo and Curtice 2014; Mughan 2015). Based on the analysis of voting determinants presented in this paper, we contend that these results substantially contribute to both existing research strands. Our results demonstrate the existence of a strong leader effect for the populist radical right vote, contrary to previous empirical investigations (Aardal and Binder 2011). These findings also largely contribute to the "charismatic leadership hypothesis" (Mudde 2007; van der Brug and Mughan 2007); they thus provide empirical support to the theories of the central bond between leaders and voters of the populist radical right - at the very least, when it comes to electoral choice (Albertazzi and McDonnell 2008). Furthermore, our models show that leader effects on the radical right vote outweigh ideological factors, such as left-right selfplacement, confirming that populist radical right leaders act as an "embodiment" of their parties' politics, to a greater extent than ideological factors (Eatwell 2002, 2018). Moreover, our results also support the particular importance of leader effects for populist radical right voters. Indeed, leader effects are more influential for voters of the populist radical right than for voters of other parties.

The disproportionate relative relevance of leader evaluations to explain the radical right vote can also motivate further reflections on the sources and the differentiated nature of leader effects for these voters. Research has demonstrated that the political communication of populist leaders is more negative, contains more personal attacks and primes more fear messages (Nai 2018). These findings suggest that populist radical right voters may be attracted by different characteristics of their leaders and by a more contentious style of political communication and aggressive campaign strategy. This is an argument deserving more careful testing in future research, mixing contributions from the political communication and voting behaviour literature. To what extent are populist leader effects incremented by negative attacks towards political opponents?

Besides their frequent use of negative campaigning, the personality profile of populist leaders is also characterized by lower agreeableness, conscientiousness, and emotional stability, while marked by higher extraversion, narcissism, and psychopathy (Nai and Coma, 2019). It would be also important to explore how these characteristics of populist radical right leaders resonate with the rest of the electorate. While these features may be appealing to populist voters, depicting politics in an "us vs. them" logic may have an adverse effect on other voters. This may translate in a form of negative personalization, in which more mainstream voters are motivated to cast a vote against populist parties due to the negative appeal of their leaders. The negative attitudes towards populist leaders by non-populist voters, and how these can affect their voting behaviour, is a potential research avenue worth exploring.

\section{Data Availability Statement}

The data that support the findings of this study are openly available. Our dataset is composed of 29 merged National Elections Studies (NES), all available online with the national producing institutions.

\section{References}

Aaldering, L. (2018). The (ir)rationality of mediated leader effects. Electoral Studies 54: 269-280. 
Aardal, B. and T. Binder (2011). Leader Effects and Party Characteristics. In K. Aarts, A. Blais and H. Schmitt (eds.), Political Leaders and Democratic Elections. Oxford: Oxford University Press (108-123).

Aarts, K., A. Blais and H. Schmitt (eds.) (2011). Political Leaders and Democratic Elections, Comparative Politics. Oxford: Oxford University Press.

van Aelst, P.T. Sheafer and J. Stanyer (2012). The personalization of mediated political communication: A review of concepts, operationalizations and key findings. Journalism 13(2): 203-220.

Albertazzi, D. and D. McDonnell (2008). Twenty-First Century Populism: The Spectre of Western European Democracy. London: Palgrave Macmillan.

Arzheimer, K. (2008). Protest, Neo-Liberalism or Anti-Immigrant Sentiment: What Motivates the Voters of the Extreme Right in Western Europe? Zeitschrift für Vergleichende Politikwissenschaft 2: $173-197$.

Balmas, M., G. Rahat, T. Sheafer and S.R. Shenhav (2014). Two Routes to Personalized Politics: Centralized and Decentralized Personalization. Party Politics 20(1): 37-51.

Barisione, M. (2009). So, What Difference Do Leaders Make? Candidates' Images and the "Conditionality" of Leader Effects on Voting. Journal of Elections, Public Opinion and Parties 19: 473-500.

Bartle, J. and P. Bellucci (2009). Political Parties and Partisanship: Social Identity and Individual Attitudes. New York: Routledge.

Betz, H.-G. (1994). Radical Right-Wing Populism in Western Europe. London: Palgrave Macmillan.

Bittner, A. (2011). Platform or Personality? The Role of Party Leaders in Elections. Oxford University Press.

Boumans, J.W., H.G. Boomgaarden and R. Vliegenthart (2013). Media Personalisation in Context: A Cross-National Comparison between the UK and the Netherlands, 1992-2007. Political Studies 61: 198-216.

van der Brug, W. (2004). Issue ownership and party choice. Electoral Studies 23(2): 209-233.

van der Brug, W., G. D'Amato, D. Ruedin and J. Berkhout (2015). The Politicisation of Migration.

New York: Routledge.

van der Brug, W. and A. Mughan (2007). Charisma, Leader Effects and Support for Right-Wing Populist Parties. Party Politics 13(1): 29-51.

Budge, I., I. Crewe and D. Farlie (eds.) (1976). Party Identification and Beyond: representations of voting and party competition. London: John Wiley.

(1983). Explaining and predicting Elections: Issue effects and Party Strategies in Twenty-Three Democracies. London: Allen \& Unwin.

Campbell, A., P. Converse and W. Miller (1960). The American Voter. New York: John Wiley.

Ceobanu, A.M. and X. Escandell (2010). Comparative Analyses of Public Attitudes Toward Immigrants and Immigration Using Multinational Survey Data: A Review of Theories and Research. Annual Review of Sociology 36: 309-328.

Curtice, J. and S. Holmberg (2005). Leaders. In J. Thomassen (ed.), The European Voter: A Comparative Study of Modern Democracies. Oxford: Oxford University Press (235-253).

Curtice, J. and M. Lisi (2014). The Impact of Leaders in Parliamentary and Presidential Regimes. In M.C. Lobo and J. Curtice (eds.), Personality Politics? The Role of Leader Evaluations in Democratic Elections. Oxford: Oxford University Press (63-84).

Dalton, R.J. (2013). Citizen Politics: Public Opinion and Political Parties in Advanced Industrial Democracies. Thousand Oaks: CQ Press. 
Dalton, R.J., I. McAllister and M.P. Wattenberg (2002). The consequences of partisan dealignment. In R.J. Dalton and M.P. Wattenberg (eds.), Parties Without Partisans: Political Change in Advanced Industrial Democracies. Oxford: Oxford University Press (37-63).

Derks, A. (2006). Populism and the Ambivalence of Egalitarianism. How Do the Underprivileged Reconcile a Right Wing Party Preference with Their Socio-Economic Attitudes? World Political Science Review 2: 175-200.

Diamond, L. and R. Gunther (2001). Political parties and democracy. Baltimore: Johns Hopkins University Press.

Eatwell, R. (2002). The Rebirth of Right-Wing Charisma? The Cases of Jean-Marie Le Pen and Vladimir Zhirinovsky. Totalitarian Movements and Political Religions 3: 1-23.

— (2018). Charisma and the Radical right. In J. Rydgren, (Ed.), The Oxford Handbook of the Radical Right. Oxford: Oxford University Press (251-268).

van der Eijk, Cees, W. van der Brug, M. Kroh and M. Franklin (2006). Rethinking the Dependent Variable in Voting Behavior: On the Measurement and Analysis of Electoral Utilities. Electoral Studies 25(3): 424-447.

Evans, G. (ed.) (1999). The End of Class Politics?: Class Voting in Comparative Context. Oxford: Oxford University Press.

Garzia, D. (2014). Personalization of politics and electoral change. London: Palgrave Macmillan.

- (2017). Voter Evaluations of Candidates. InK. Arzheimer, J. Evans and M.S. Lewis-Beck (eds.), The SAGE Handbook of Electoral Behaviour. London: SAGE.

Garzia, D. and A. De Angelis (2016). Partisanship, leader evaluations and the vote: disentangling the new iron triangle in electoral research. Comparative European Politics 14(5): 604-625.

Garzia, D., F.F. Silva and A. De Angelis (2020). Image that Matters: News Media Consumption and Party Leader Effects on Voting Behavior. International Journal of Press/Politics 25(2): 238259.

Hatton, T.J. (2017). Public Opinion on Immigration in Europe: Preference versus Salience (No. DP12084), CEPR Discussion Papers. London: Centre for Economic Policy Research.

van Hauwaert, S.M. and S. van Kessel (2018). Beyond protest and discontent: A cross-national analysis of the effect of populist attitudes and issue positions on populist party support. European Journal of Political Research 57(1): 68-92.

Heinisch, R. (2003). Success in opposition - failure in government: explaining the performance of right-wing populist parties in public office. West European Politics 26(3): 91-130.

Heinisch, R. and O. Mazzoleni (2016). Understanding Populist Party Organisation: The Radical Right in Western Europe. London: Palgrave Macmillan.

Hernández, E. and H. Kriesi (2018). The electoral consequences of the financial and economic crisis in Europe. European Journal of Political Research 55(2): 203-224.

Holmberg, S. and H. Oscarsson (2011). Party Leader Effects on the Vote. In K. Aarts, A. Blais and H. Schmitt (eds.), Political Leaders and Democratic Elections. Oxford: Oxford University Press.

Ignazi, P. (2003). Extreme Right Parties in Western Europe. Oxford: Oxford University Press.

Immerzeel, T., H. Coffé and T. van der Lippe (2015). Explaining the gender gap in radical right voting: A cross-national investigation in 12 Western European countries. Comparative European Politics 13: 263-286.

Inglehart, R. and P. Norris (2017). Trump and the Populist Authoritarian Parties: The Silent Revolution in Reverse. Perspectives on Politics 15(2): 443-454.

Ivarsflaten, E. (2008). What Unites Right-Wing Populists in Western Europe?: Re-Examining Grievance Mobilization Models in Seven Successful Cases. Comparative Political Studies 41(1): 3 23. 
Karvonen, L. (2010). The Personalisation of Politics: A Study of Parliamentary Democracies. Colchester: ECPR Press.

Kefford, G. and D. McDonnell (2018). Inside the personal party: Leader-owners, light organizations and limited lifespans. The British Journal of Politics and International Relations 20(2): 379-394.

van Kessel, S. (2015). Populist Parties in Europe: Agents of Discontent? Basingstoke: Palgrave Macmillan.

Kestila-Kekkonen, E. and P. Söderlund (2014). Party, Leader Or Candidate? Dissecting the RightWing Populist Vote in Finland. European Political Science Review 6(4): 641-662.

King, A. (ed.). (2002). Leaders' Personalities and the Outcomes of Democratic Elections. Oxford: Oxford University Press.

Kriesi, H., E. Grande, M. Dolezal, M. Helbling, D. Höglinger, S. Hutter and B. Wüest (2012). Political Conflict in Western Europe. Cambridge: Cambridge University Press.

— (2014). The Populist Challenge. West European Politics 37(2): 361-378.

Kriesi, H. and J. Schulte-Cloos (2020). Support for Radical Parties in Western Europe: Structural Conflicts and. Political Dynamics. Electoral Studies 65 - online.

de Lange, S.L. and D. Art (2011). Fortuyn versus Wilders: An Agency-Based Approach to Radical Right Party Building. West European Politics 34(6): 1229-1249.

Lobo, M.C. (2008). Parties and Leader Effects: Impact of Leaders in the Vote for Different Types of Parties. Party Politics 14(3): 281-298.

Lobo, M.C. and J. Curtice (eds.) (2014). Personality Politics?: The Role of Leader Evaluations in Democratic Elections. Oxford: Oxford University Press.

Manin, B. (1995). Principes du Gouvernement Représentatif. Paris: Champs Flammarion.

Mazzoleni, G. (2008). Populism and the Media. In D. Albertazzi and D. McDonnell (eds.), TwentyFirst Century Populism. London: Palgrave Macmillan (49-64).

McAllister, I. (2007). The Personalization of Politics. In R.J. Dalton and H.-D. Klingemann (eds.), The Oxford Handbook of Political Behavior. New York: Oxford University Press (571-588).

McDonnell, D. (2016). Populist Leaders and Coterie Charisma. Political Studies 64(3): 719-733.

Mény, Y. and Y. Surel (2002). Democracies and the populist challenge. Basingstoke: Palgrave Macmillan.

Meyrowitz, J. (1985). No sense of place: the impact of electronic media on social behavior. Oxford: Oxford University Press.

Moffit, B. and S. Tormey (2014). Rethinking Populism: Politics, Mediatisation and Political Style. Political Studies 62(2): 381-397.

— (2016). The Global Rise of Populism: Performance, Political Style, and Representation. Redwood: Stanford University Press.

Mudde, C. (2007). Populist Radical Right Parties in Europe. Cambridge: Cambridge University Press.

- (2010). The Populist Radical Right. A Pathological Normalcy. West European Politics 33(6): $1167-1186$.

Mudde, C. and C. Rovira Kaltwasser (2018). Studying Populism in Comparative Perspective: Reflections on the Contemporary and Future Research Agenda. Comparative Political Studies 51 (13): 1667-1693.

Mughan, A. (2015). Parties, conditionality and leader effects in parliamentary elections. Party Politics 21(1): 28-39.

Nai, A. (2018). Fear and loathing in populist campaigns? Comparing the communication style of populists and non-populists in elections worldwide. Journal of Political Marketing.

Nai, A. and F. Martínez i Coma, (2019). The personality of populists: provocateurs, charismatic leaders, or drunken dinner guests? West European Politics 42(7): 1337-1367. 
Pedersen, H.H. and G. Rahat. (2019). Introduction: Political personalization and personalized politics within and beyond the behavioural arena. Party Politics (June 2019).

Petrocik, J.R. (1996). Issue Ownership in Presidential Elections, with a 1980 Case Study. American Journal of Political Science 40(3): 825-850.

Pirro, A. (2015). The Populist Radical Right in Central and Eastern Europe Ideology, impact, and electoral performance. London: Routledge.

Poguntke, T. (1987). New politics and party systems: The emergence of a new type of party? West European Politics 10(1): 76-88.

Poguntke, T. and P. Webb (eds.) (2005). The Presidentialization of Politics: A Comparative Study of Modern Democracies. Oxford: Oxford University Press.

- (2018). Presidentialization, Personalization and Populism. The Hollowing out of Party Government. In W. Cross, R. Katz and S. Pruysers (eds.), The Personalization of Democratic Politics and the Challenge for Political Parties. London: Rowman \& Littlefield International, Ltd; ECPR Press (181-196).

Rahat, G. and T. Shaefer (2007). The Personalization(s) of Politics: Israel, 1949-2003. Political Communication 24(1): 65-80.

Rahat, G. and O. Kenig (2018). From Party Politics to Personalized Politics?: Party Change and Political Personalization in Democracies. Oxford: Oxford University Press.

Rama, J. and G. Cordero (2018). Who are the losers of the economic crisis? Explaining the vote for right-wing populist parties in Europe after the Great Recession. Revista Española de Ciencia Política 48: 13-43.

Rooduijn, M., S. van Kessel, C. Froio, A. Pirro, S. de Lange, D. Halikiopoulou, P. Lewis, C. Mudde and P. Taggart (2019). The PopuList: An Overview of Populist, Far Right and Far Left and Eurosceptic Parties in Europe [Dataset].

Rosema, M. (2006). Partisanship, Candidate Evaluations, and Prospective Voting. Electoral Studies 25(3): 467-488.

Rydgren, J. (2005). Movements of Exclusion: Radical Right-Wing Populism in the Western World. New York: Nova Publishers.

- (2007). The Sociology of the Radical Right. Annual Review of Sociology 33: 241-262.

Schumacher, G. and M. Rooduijn (2013). Sympathy for the 'Devil'? Voting for Populists in the 2006 and 2010 Dutch General Elections. Electoral Studies 32(1): 124-133.

Silva, F.F. (2018). Fostering turnout?: Assessing party leaders' capacity to mobilize voters. Electoral Studies 56: 61-79.

Silva, F.F. and P. Costa (2019). Do we need warm leaders? Exploratory study of the role of voter evaluations of leaders' traits on turnout in seven European countries. European Journal of Political Research 58(1): 117-140.

Silva, F.F., D. Garzia and A. De Angelis. (2019). From party to leader mobilization? The personalization of voter turnout. Party Politics (June 2019).

Takens, J.H., J. Kleinnijenhuis, W.H. van Atteveldt and A.M.J. van Hoof (2015). Party leaders in the media and voting behavior: Priming rather than learning or projection. Political Communication 32(2): 249-267.

Thomassen, J. (1976). Party identification as a cross-cultural concept. Its meaning in the Netherlands. In I. Budge, I. Crewe and D. Farlie (Eds.), Party Identification and Beyond. London: John Wiley and Sons.

Thomassen, J. (ed.) (2005). The European Voter: A Comparative Study of Modern Democracies. Oxford: Oxford University Press. 
Thomassen, J. and M. Rosema (2009). Party Identification Revisited. In J. Bartle and P. Bellucci (Eds.) Political Parties and Partisanship: Social Identity and Individual Attitudes. New York: Routledge (42-59).

Weber, M. (1978). Economy and Society: An Outline of Interpretive Sociology. Berkeley: University of California Press.

Werts, H., P. Scheepers and M. Lubbers (2013). Euro-scepticism and radical right-wing voting in Europe, 2002-2008: Social cleavages, socio-political attitudes and contextual characteristics determining voting for the radical right. European Union Politics 14(2): 183-205.

Wodak, R. (2015). The Politics of Fear: What Right-Wing Populist Discourses Mean. London: Sage.

Zhirkov, K. (2014). Nativist but not alienated A comparative perspective on the radical right vote in Western Europe. Party Politics 20(2): 286-296.

\section{Supporting Information}

Additional Supporting Information may be found in the online version of this article: Supplementary Material

Elie Michel is a Senior Researcher and Lecturer at the Department of Political Science at the University of Lucerne. His research interests include political behavior, political parties, European politics and the Radical Right. Address for correspondence: University of Lucerne, Department of Political Science, Frohburgstrasse 3, Lucerne 6002, Switzerland; Email: elie.michel@unilu.ch

Diego Garzia is Assistant Professor of Political Science at the University of Lausanne. His current research project on "negative voting" in comparative perspective is funded by an SNSF Eccellenza Professorial Fellowship of the Swiss National Science Foundation, 2020-2024. diego.Garzia@unil.ch

Frederico Ferreira da Silva is currently an SNSF Senior Researcher at the University of Lausanne, Switzerland. $\mathrm{He}$ obtained his $\mathrm{PhD}$ in Social and Political Sciences from the European University Institute in 2019. He works on elections, public opinion and voting behavior. frederico.silva@unil.ch

Andrea De Angelis is Senior Researcher and Lecturer at the Department of Political Science, University of Lucerne. His research interests include political behavior, political methodology, political communication and political psychology. andrea.deangelis@unilu.ch 